\title{
METAPHORS OF LIFE INSURANCE AND HOME APPLIANCE ON YOUTUBE ADVERTISEMENTS VIDEOS
}

\section{METAFORA PADA VIDEO IKLAN ASURANSI JIWA DAN IKLAN PERABOT RUMAH TANGGA DI LAMAN YOUTUBE}

\author{
Lilik Rochmah Agustina \\ Masriatus Sholikhah \\ STKIP PGRI Jombang \\ lilikrochmah@yahoo.co.id \\ masriatus.sholikhah@gmail.com
}

\begin{abstract}
The aim of this research is to explore metaphors in life insurance and home appliance on YouTube advertisements videos by employing pragmatics perspective. To accomplish the goal of the research, qualitative descriptive is employed to figure out of both two research questions. Furthermore, to know the kinds of metaphor, researchers work on theory proposed by Lakoff and Johnsen (2003) for fundamental metaphor theory, then, conceptual metaphor theory proposed by Kovecses (2010); and the last is pictorial metaphor theory proposed by Forceville (2002). At last, it can be seen that the type of metaphor are pictorial metaphor for SINAR MAS MSIG life insurance and LG home appliance advertisements. Further, in term of conceptual metaphor researchers found two type of metaphor; structural metaphor and ontological metaphor in Thai life insurance and Philips home appliance advertisements. As the closing, researchers figured out that among the four of life insurance and home appliance advertisements issued in YouTube apply the persuasive strategy to influence the audiences. These advertisements eventually are influential in inviting customers' attention since the application of metaphors and persuasive strategies.
\end{abstract}

Keywords: Metaphor, Source Domain, Target Domain, YouTube Advertisement Video, Persuasion

\begin{abstract}
Abstrak
Penelitian ini bertujuan untuk menyelidiki metaphor yang terdapat pada video iklan asuansi jiwa dan iklan perabot rumah tangga di laman Youtube melalui pendekatan Pragmatic. Untuk mencapai tujuan penelitian, pendekatan kualitatif diaplikasikan untuk menjawab dua permasalahan penelitian. Lebih lanjut, untuk mengetahui jenis metafor yang digunakan pada objek penelitian, peneliti menggunakan teori dari Lakoff dan Johnsen (2013) tentang Fundamental Metaphor, Conseptual Metaphor dari Kovecses (2010), dan teori Pictorial Metaphor dari Forceville (2002). Akhirnya, dapat diketahui bahwa jenis metaphor yang di temukan dalam empat iklan di laman Youtube adalah pada iklan asuransi jiwa Sinar Mas MISG life dan iklan perabot rumah tangga LG terdapat lebih dominan Pictorial Metaphor. Selain itu, pada iklan asuransi jiwa Thailand dan iklan lampu Philip cenderung menggunakan Conceptual Metaphor dengan temuan 2 sub jenis dominan yakni Structural Metaphor dan Ontoligical
\end{abstract}


Metaphor. Sebagai penghujung temuan, peneliti menemukan fakta bahwa keempat iklan asuransi jiwa dan iklan perabot rumah tangga yang ditayangkan pada laman Youtube menggunakan beberapa jenis strategy persuasive untuk mempengaruhi khalayak. Secara jelas, iklan-iklan tersebut bersift persuasive dalam mengundang perhatian dan minat para konsumen dengan menggunakan unsur-unsur metafora dan strategi persuasif.

Kata kunci: metafora, domain sumber, domain target, video iklan mber, domain target, video iklan Youtube, persuasi.

\section{INTRODUCTION}

Taverniers (2002:5) states that a number of authors Grice (1989: 34), in the framework of Grice's theory of the Cooperative Principle, metaphor is treated as a specific type of conversational implicature, Mack (1975) and Loewenberg (1977) deal with metaphor in the framework of speech act theory, and propose to conceive of metaphor as a type of speech act. For instance, the utterance as communicative illocutionary act, which called acknowledgment type, 'My friend's mother is a head department right now', is categorized in metaphor. Pragmatics perspective concern to speaker's meaning because the utterance is not just for delivered without communication intention. The utterance above had the context that the speaker intends to express congratulating for the top position of his/her friend's mother.

This research conducted in metaphor applied with pragmatics perspective especially in the illocutionary act because the object of this research is YouTube advertisements videos that full of communication intention of the copywriter for persuading the viewers as the purpose. A number of reasons why the researcher applied metaphor as the theory with pragmatics perspective in YouTube advertisements videos, metaphor expression presented in the advertisement by certain context for getting multiple interpretations from the viewers. Furthermore, the message of metaphor in advertisement delivers moral or social value for life and metaphor in pragmatics perspective commonly promote the product in form of inspiration and motivation story.

Brad and Debra (2009:27) state, "YouTube is now an international phenomenon with more than 200 million visitors arriving at the site every month." It means YouTube is available in everywhere through all gadgets of thousand million people in the world making easily to reach viewers and it proved that YouTube influences the people. Moreover, the 
certain advertisement video on YouTube has more thousand viewers watch the video so far. For instance, the brand advertisement of life insurance 'Thai Life Insurance in the Unsung Hero episode' gets more than twenty million viewers watched the video and inspired for starting share each other.

The message of advertisement will be delivered easily by employing tactics of persuasive in the advertisement. Tactics of Persuasive in the advertisement is fundamentally in positive notion because in success business especially in the advertisement is applying particular tactics of persuasive in order it will change it in some way by choice, in this case, to decide the best choice. However, the commercial is one of the appropriate places for metaphors, which are best analyzed by using pragmatics perspective. Those are an attractive and efficient way for the copywriter to make positive claims for their products, brands, or services.

The word metaphor surely has the certain meaning. The word 'metaphor' derives from two Greek roots that appeared in English in 1533. Two Greek roots are meta has meaning 'over, beyond' and pheiren has meaning 'to carry, transfer'. Hence, those have sense of the word is to carry a word over and beyond its original meaning by applying it to something else (Grothe, 2008:9). The concept of metaphor will be understood well by understanding firstly simple structural of two terms that often make people confused when defining a metaphor because those terms are capturing a thing by relating to something else.

Moreover, understanding literal meaning played the role as the basic concept of meaning language before understanding the non-literal meaning. For instance, Love is A journey: Literally, love (noun) means an intense feeling of deep affection; is (to be in present form) means to show singularity; $A$ (determiner) means a modifying word that determines the kind of reference a noun, journey (noun) means travelling from one place to another. Contextually the sentence 'Love is A journey' provides meaning a starting place, a path, and an ending place when in relationship applied hope for adventure and possibility of spiritual change in a course of travel. Its meaning above is metaphorical naturally which contains implicit meaning and contextual as a force.

Lakoff and Johnsen (2003:4) state, "Metaphor is pervasive in everyday life, not just in language but in thought and action. Our ordinary conceptual system, in terms of which we both think and act, is fundamentally metaphorical in nature." It means not only people's language, which is metaphorical but also people thought and people's action are within metaphorical naturally. In daily life, people think about the definition or concept of a thing 
or even phenomena of social life by comparing a thing in a term to another, in order to help them understanding something well.

Kovecses (2010) divided conceptual metaphor into three types, which classified personification as a form of ontological metaphor. Conceptual metaphor is a cognitive structure that represents a thing in a term to another by mapping a certain concept. Conceptual metaphor appears in a form of a phrase or a sentence. It supports by Mladenov (2006:9) states, "As a term 'conceptualizing metaphors' is understood to be merely the search for a reappearance of something." Two terms that consist in conceptual metaphor, such as source domain and target domain. Source domain is more clearly concept and more typically concrete than target domain, which are abstract concepts, lack of clarity delineation, and diffuse. The pictorial metaphor is categorized in nonverbal metaphor usually it is used to promote something and persuade someone in form of billboard or poster. The pictorial metaphor is not only appearing in form of billboard or poster but also it is appearing in a film or even in an advertisement. However, the pictures are obviously provided by pictorial metaphor. Forceville (2002:65) said that pictorial metaphor should show an awareness that a metaphor has two distinctive terms, those two distinctive terms labeling primary subject and secondary subject.

Persuasive is the key in promoting a product especially a product that is in form of video and billboard. There are no products without any message inside in. Amstrong, Scott J (2010, 180-216) state that there are thirteen elements of constructing messages to communicate information through words, pictures, sounds, and color. Those thirteen elements are argument, clarity, forceful text, interesting text, tone, word selection, word play, metaphor and figure of speech, simplicity, informative illustration, informative color, ad consistency, and disclaimers and corrective advertising.

\section{RESEARCH METHOD}

This research applies qualitative research because this research had the aim to understand a social phenomenon. The data were analyzed by interpreting the meaning of metaphors on YouTube advertisements videos. This research is conducted in a natural setting because it taken from YouTube advertisement videos that the researcher did not involve to create or give any idea on YouTube advertisements videos. 
Afterward, four steps for analyzing the data, they follow as organizing the data by classified based on the category of data, then, gave a label to each selected data by codes. Furthermore, researcher interpreted the meaning of metaphors that presented in life insurance and home appliance on YouTube advertisements videos, the last, the conclusion taken after data analysis of life insurance and home appliance on YouTube advertisements videos. Thus, in this present research, the researcher applied theory triangulation because researcher applied more than one theory to conduct this present research.

\section{DISCUSSION}

\section{a. Kinds of metaphor}

The researcher found pictorial metaphor in life insurance advertisement video by Sinarmas MSIG Life. Sinarmas MSIG Life categorized as Pictorial Metaphor because the ad video presented the scenes, which were mostly dominance pictures than utterances in order scenes captured in form of pictures most reflected SINARMAS MSIG LIFE IS HUMAN PROTECTOR. The statements above based on Forceville's theory in Pictorial Metaphor that it would be difficult to talk about 'pictorial metaphor' without pictures then advertisements are very rarely of a purely pictorial nature. The primary subject was Sinarmas MSIG Life and the second subject was Human Protector, which the characteristics of Sinarmas MSIG Life similar with protector and it explained by sequences of events. The copywriter employed a red candle, fire, shaking fire, desolate circumstance, and two different hands. A red candle was associated as human body; while red color meant dangerous and in case of emergency, fire meant as the soul of human, shaking fire meant as the level of ill and problem of human, desolate circumstance as the symbol of comfort zone, and two different hands as cooperation of both Sinarmas Bank and Mitsui Sumitomo Group. Every human was going to die as a flame candle was going to extinguish. The process of human's life always got risks especially in healthy as flame candle always got into trouble with the wind. Life insurance of Jiwa Sinarmas MSIG presented as protection of human as a flame candle. However, Asuransi Jiwa Sinarmas MSIG just protects the human from the risks especially the healthy, and it never guaranteed the immortality of human life. Based on Forceville's theory that the advertisement messages that will be examined, then, are 'word and image messages'. It revealed the message in the last screen captures that everybody shall 
taste the death, so this message categorized moral value that nobody knows when and how people will die.

The researcher found the conceptual metaphor in home appliance advertisement video by Philips. The utterances uttered by monolog in an advertisement video of YouTube, the utterances in form of sentence based on Kovecses's theory that Conceptual metaphor appears in a form of a phrase or a sentence. Those utterances categorized as Conceptual Metaphor, which specified categorized as Ontological Metaphor because the utterances told Philips was given human quality, here Philips was personified because Philips was nonhuman or just a thing (the brand of lamp), and meanwhile, personification is seeing something nonhuman as human by giving human entities. Obviously, ontological metaphors are those where the physical object is further specified as being a person. The statements above based on the theory from Lakoff and Johnsen that Physical object is specified as being a person obviously include in ontological metaphor because the variety experiences with nonhuman entities are comprehended by human activities, motivations, and characteristics.

Afterward, the researcher found that conceptual metaphor in home appliance advertisement video by Philips. The data in form of utterances that described below:

(1) It can set the mood. (H2-U2-CM)

(2) It can bring us together. (H2-U4-CM)

(3) It can surprise us. (H2-U6-CM)

(4) It can even move us. (H2-U8-CM)

The utterances above uttered by monolog in an advertisement video in YouTube, the utterances in form of sentence based on Kovecses' theory that Conceptual metaphor appears in a form of a phrase or a sentence. Those utterances categorized as Conceptual Metaphor, which specified categorized as Ontological Metaphor because the utterances told Philips was given human quality, here Philips was personified because Philips was nonhuman or just a thing (the brand of lamp), and meanwhile, personification is seeing something nonhuman as human by giving human entities. Obviously, ontological metaphors are those where the physical object is further specified as being a person. The statements above based on the theory from Lakoff and Johnsen that Physical object is specified as being a person obviously include in ontological metaphor because the variety experiences with nonhuman entities are comprehended by human activities, motivations, and characteristics. 
Firstly, the code H2-U2-CM was the utterance $\underline{I t}$ can set the mood was the second conceptual metaphor, which was categorized as ontological metaphor type. The italicunderlined word $\underline{I t}$ was referred to Philips and $\underline{s e t}$ was the human entity. The metaphor was much more specific, it captured in PHILIPS IS THE ACTOR. The copywriter tried to give the idea that Philips as the Actor. It made audience felt happy by played role in serial comedy, made audience felt sad by played role in serial sadness drama, made audience felt fear by played role in horror movie, made audience felt angry by played role in crime movie, and made us amazed by played role in science movie. In this case, Philips as resemblance as the Actor, it was to set the mood of anyone around by the lamp model, the level of lighting, and lamp cover color.

Secondly, the code H2-U4-CM was the utterance it can bring us together was the third conceptual metaphor, which specified categorized as ontological metaphor type. The

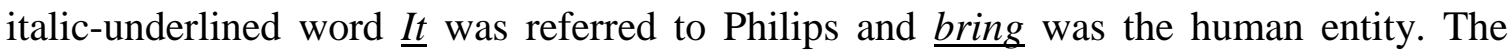
metaphor was much more specific, it captured in PHILIPS IS THE DRIVER. The copywriter tried to give the idea that it picked people up by rode them to their destination. In this case, Philips as resemblance as the Driver, it was to attract people togetherness by the lamp model, the level of lighting, and lamp cover color.

Thirdly, the code H2-U6-CM was the utterance it can surprise us was the fourth conceptual metaphor, which specified categorized as ontological metaphor type. The italicunderlined word $\underline{I t}$ was referred to Philips and surprise was the human entity. The metaphor was much more specific, it captured in PHILIPS IS THE MAGICIAN, the copywriter tried to give the idea that it attracted people, made people curiosity, made people nervous, and expected something. In this case, Philips as resemblance as the Magician, it was to surprise people by the lamp model, the level of lighting, and lamp cover color.

Fourthly, the code H2-U8-CM was the utterance it can even move us was the fifth conceptual metaphor, which specified categorized as ontological metaphor type. The italicunderlined word $\underline{I} \underline{t}$ was referred to Philips and move was the human entity. The metaphor was much more specific, it captured in PHILIPS IS THE LOVER, the copywriter tried to give the idea that it can control the emotion of someone even people, intended sexual love, and encouraged people to something enthusiastically. In this case, Philips as resemblance as the Lover, it was to move someone even people by the lamp model, the level of lighting, and lamp cover color. It revealed the message that Philips brings happiness 


\section{General Tactics of Message in Persuasive Advertising}

General tactics of the message in life insurance and home appliance on YouTube advertisements videos is to persuade the audiences to involve eight elements such as clarity, forceful text, tone, metaphor or figure of speech, simplicity, informative illustration, informative color, and Ad consistency in two advertisements such as Sinarmas MSIG Life and LG. Then, it involves eleven elements namely argument, clarity, forceful text, tone, word selection, wordplay, metaphor or figure of speech, simplicity, informative illustration, informative color, and Ad consistency in two advertisements such as Thai Life Insurance and Philips.

In conclusion, to persuade the audience, the copywriter obviously applies metaphors and general tactics of the message in life insurance and home appliance advertisements videos on YouTube.

\section{b. CONCLUSION}

In conclusion, to persuade the audience, the copywriter obviously applies metaphors and general tactics of the message in life insurance and home appliance advertisements videos on YouTube. This present research is suggested for the following researcher who is interested in the similar research to have a deeper analysis by choosing one of the metaphors theory. It can be pictorial metaphor theory proposed by Forceville and conceptual metaphor theory proposed by Kovecses. This suggestion is made due to the limited time that makes the researcher cannot touch these points into a more detail analysis.

\section{REFERENCES}

Amstrong, Scott J. 2010. Persuasive Advertising. New York: Palgrave Macmillan.

Brad and Debra. 2009. How to Make Money with YouTube. New York: Mc Graw Hill, Inc.

Corradi, Gemma F. 1995. The Metaphoric Process. London: Routledge.

Creswell, John W. 2009. Research design: Qualitative, quantitative, and mixed methods approaches $3^{\text {rd }}$ Ed. USA: Sage Publications, Inc.

Denzin. 1978. The Research Act: A Theoretical Introduction to Sociological Methods $2^{\text {nd }}$. New York: Mc Graw Hill, Inc. 
Edward at all. 2008. Go Figure! New Directions in Advertising Rhetoric. USA: M.E. Sharpe, Inc.

Eubank, Philip. 2000. A War of Words in the Discourse of Trade. USA: The Broad of Trustees.

Forceville, Charles. 2002. Pictorial Metaphor in Advertising. London: Routledge.

Griffiths, Patrick. 2006. An Introduction to English Semantics and Pragmatics. Edinburgh: Edinburgh University Press Ltd.

Grothe, Mardy. 2008. I Never Metaphor I Didn't Like. Australia: HarperCollins Publishers (Australia) Pty. Ltd.

Kovecses, Zoltan. 2010. Metaphor A Practical Introduction $2^{\text {nd }}$ Ed. Oxford: Oxford University Press.

Lakoff and Johnsen. 2003. Metaphors We Live By. London: The University of Chicago Press.

Lakoff, Robin T. 2000. The Language War. California: University of California Press.

Leezenberg, Michiel. 2001. Contexts of Metaphor. Amsterdam: Elsevier Science Ltd.

Levinson, Stephen C. 1983. Pragmatics. UK: Cambridge University Press.

Mladenov, Ivan. 2006. Conceptualizing Metaphors. USA: Routledge.

O’Shaughnessy and Nicolas. 2004. Persuasion in Advertising. USA: Routledge.

Septiana at all. 2013. An Analysis of Metaphor Used by Teenagers and Adults in Daily Conversation in Minangkabau Language. Thesis. Padang: Language and Literature Faculty. Padang State University.

Sommer and Dorrie. 2001. Metaphors Dictionary. USA: Visible Ink Press TM

Taverniers, Miriam. 2002. Metaphor. In: Jef Verschueren, Jan-Ola Östman, Jan Blommaert and Chris Bulcaen (eds.) Handbook of Pragmatics 2002. Amsterdam: Benjamins.

Zhang and Gao. 2009. An Analysis of Conceptual Metaphor in Western Commercial Advertisements. Asian Social Science. 5: 97-104. 